TARNOWSKIE STUDIA TEOLOGICZNE 36 (2017) NR 1, S. 99-118

http://dx.doi.org/10.15633/tst.2326

ks. Piotr Jaworski ${ }^{1}$

TARNÓW

\title{
Rys historyczny posługi kapelanów wojskowych w Polsce do czasów utworzenia stałego duszpasterstwa
}

\section{Tradycje duszpasterstwa wojskowego}

Relacje z działań wojennych na przestrzeni dziejów ludzkości, zachowane $\mathrm{w}$ literaturze ${ }^{2}$, nieodmiennie wskazują na nierozdzielność sfery sacrum i bellum. Potwierdzają, że wśród wojsk biorących udział w walkach znajdowali się kapłani różnych religii. Możemy więc bez popełnienia błędu stwierdzić, że historia duszpasterstwa wojkkowego ${ }^{3}$ ma korzenie tkwiące w starożytności i jest integralnie związana z powszechną historią wojskowości. Od najdawniejszych czasów bowiem w wojskach greckich, rzymskich, żydowskich czy innych spotykano osoby pełniące posługi religijne ${ }^{4}$. W wojskach żydowskich kapłani strzegli Arki Przymierza, zaś przed bitwą stając na czele

1 Piotr Jaworski - ksiądz katolicki, absolwent Papieskiej Akademii Teologicznej w Krakowie Wydział Teologiczny Sekcja w Tarnowie (2005), obecnie wikariusz w parafii św. Józefa i Matki Boskiej Fatimskiej w Tarnowie, kapelan szpitala im. Szczeklika w Tarnowie.

2 Wśród literatury powstałej w starożytności, a dotyczącej prowadzonych wojen należy wymienić m.in. Iliadę Homera, Wojne galijską Gajusza Juliusza Cezara, Corpus Caesarianum Gajusza Juliusza Cezara, Dawne dzieje Izraela Józefa Flawiusza, Germanię Publiusza Korneliusza Tacyta.

3 Artykuł powstał na podstawie pracy magisterskiej pt. Organizacja duszpasterstwa wojskowego wyznania rzymskokatolickiego w Siłach Zbrojnych Rzeczypospolitej Polskiej w latach 1918-1939. Studium historyczno-prawne napisanej pod kierunkiem ks. dr. Władysława Kostrzewy na seminarium z prawa wyznaniowego.

4 Por. E. Dąbrowski, Religie świata, Warszawa 1957, s. 251-279; E. Dąbrowa, Rozwój i organizacja armii rzymskiej (do początku wieku III n.e.), „Filomata” $1990 \mathrm{nr} 3$ - specjalny, s. 412420 . 
szyków bojowych, zachęcali żołnierzy do wytrwania w walce w imię Boga Taka sytuacja miała także miejsce od IV wieku n.e. w legionach rzymskich, gdy chrześcijaństwo za sprawą Konstantyna Wielkiego $(306-337)^{6}$ stało się religią dozwoloną.

Regulacje Konstantyna Wielkiego zapewniające w efekcie znaczący wpływ religii chrześcijańskiej i Kościoła na niemal wszystkie dziedziny życia państwa, społeczeństwa i jednostek sprawiły, że w średniowieczu powstał światopogląd zwany teocentryzmem ${ }^{7}$. Jego rezultatem była m.in. wszechobecność duchowieństwa, wśród którego byli kapelani, o czym m.in. informuje Walahfrid Strabo ${ }^{8}$. Stwierdza on, że na dworze królów frankońskich znajdowali się kapelani. Nazwa wywodziła się, jak stwierdza od kapy św. Marcina9 ${ }^{9}$ którą królowie frankońscy czcili i przechowywali w kaplicy pałacowej. Ponieważ św. Marcin był w latach młodości żołnierzem rzymskich legionów, zrodził się zwyczaj zabierania tejże kapy wraz z innymi relikwiami na wyprawy wojenne ${ }^{10}$. Tych spośród przedstawicieli licznego kleru, którzy strzegli kapy św. Marcina w kaplicy i nosili ją na wojnę, zaczęto z czasem nazywać kapelanami ${ }^{11}$.

5 Por. Pwt 20; P. C. Thompson, From its European antecedents to 1791. The United States Army Chaplaincy, vol. 1, Washington 1978, s. xII; J. H. Hertz, The Pentateuch and Hofthoras, London 1965, s. 831.

${ }^{6}$ Por. J. Wolski, Historia powszechna. Starożytność, Warszawa 2002, s. 452.

7 Teocentryzm to światopogląd, według którego życie człowieka oraz wszelka jego aktywność winny skupiać się wokół Boga i wiary. Bóg powinien być punktem odniesienia dla ludzkiej aktywności w sztuce, codziennym życiu, literaturze, nauce, sposobie myślenia itd. Szerzej na temat teocentryzmu zob. m.in. J. Le Goff, Kultura średniowiecznej Europy, Gdańsk-Warszawa 2002.

${ }^{8}$ Walahfrid von der Reichenau (lub Walahfried), zwany Zezowatym (łac. Strabo) (ur. ok. 808/809; zm. 18 sierpnia 849) - mnich benedyktyński, poeta i teolog. Opat klasztoru na wyspie Reichenau $(838,842-849)$. Jeden z najbardziej wpływowych pisarzy i nauczycieli czasów Karolingów. W latach 829-838 sprawował funkcję wychowawcy księcia Karola II na dworze Karolingów.

9 Marcin z Tours (łac. Martinus Turonensis), (ur. w roku 317 lub 335 w Sabarii w Pannonii zm. 8 listopada 397 w Candes nad rz. Vienne) - biskup Tours, święty Kościoła katolickiego i prawosławnego. Płaszcz Marcina uchodził za frankońską relikwię państwową, toteż zabierano go na wszystkie wojenne wyprawy. W czasach pokoju ta kosztowna relikwia była przechowywana w pałacu króla w Paryżu. Podobno Sainte-Chapelle, kaplica pałacowa w Paryżu, w której przechowywano wiele ważnych relikwii, swą nazwę wzięła także od płaszcza Marcina (łac. cappa to płaszcz, ponadto capella - kaplica).

${ }^{10}$ Por. J. Radziszewski, $Z$ dziejów duszpasterstwa wojskowego $w$ Polsce (do zakończenia I wojny światowej), „Wojsko i Wychowanie” 1990 nr 10, s. 40.

${ }_{11}$ Zob. Valafridi Strabi, De Ecclesiasticarum rerum exordiis et incrementis, liber unus, w: Valafridi Strabi, Opera omnia, accurante J.-P. Migne (Patrologiae Cursus Completus, Series Lati- 
W terminologii prawnej określenie kapelan (capellanus) pojawiło się we wczesnym średniowieczu i etymologicznie wywodziło się od łacińskiego słowa capella oznaczającego kaplicę lub mały kościół w odróżnieniu od świątyni parafialnej ${ }^{12}$. Początkowo dokumenty prawne nie wyróżniały kapelanów wojskowych na stałe związanych z armią i włączonych w hierarchię służbową. Czynność tę pełnili bowiem kapelani królewscy, hetmańscy lub dworscy w wypadku wojny. W okresie od vi do x wieku można zaobserwować stopniowy wzrost praktyk religijnych w wojsku wyrażający się m.in. obowiązkowymi modlitwami, postami przed bitwą oraz wznoszeniem okrzyku przed starciem „Krzyż zwycięża!”" Poczynając od viII wieku, w prawie synodalnym spotykamy pierwsze wzmianki o kapelanach wojskowych ${ }^{14}$. Przykładem mogą być uchwały synodu w Ratyzbonie z 742 roku, na mocy których król lub najwyższy dowódca miał mieć przy sobie jednego lub dwóch biskupów z odpowiednią liczbą kapelanów ${ }^{15}$. Synod nakładał na dowódców mniejszych jednostek wojskowych obowiązek posiadania $\mathrm{w}$ swoich szeregach przynajmniej jednego kapelana, który miał troszczyć się o spowiedź żołnierzy ${ }^{16}$. Kapitularz Karola Wielkiego z 769 roku zakazał kapelanom czynnego udziału w walkach, zastrzegając „by kapłani ani chrześcijańskiej, ani pogańskiej krwi nie przelewali” ${ }^{17}$. Decyzję

na, 114), Paris 1876 . „Dicti sunt autem capellani a cappa beati Martini quam reges Francorum ab objutorium victoriae in prediis solebant sccum habere: quam ferentes et custodientes cum caeteris sanctorum reliquiis clerici, capellani coeperunt vocari” (za J. Sójka, Posługi duszpasterskie przy wojskach polskich w wiekach średnich, „Acta Universitatis Lodziensis. Folia Historica” $1994 \mathrm{nr}$ 50, s. 95).

${ }_{12}$ Por. T. Pawluk, Prawo kanoniczne według Kodeksu Jana Pawła II, t. 2: Lud Boży, jego nauczanie i uświęcanie, Olsztyn 1986, s. 289.

${ }^{13}$ K. Kościelniak, Naśladownictwo islamskiej ideologii dżihadu w „Tactica” cesarza Leona VI (886-912) w kontekście zmagań bizantyńsko-muzułmańskich od VII do X wieku, w: Byzantina Europaea. Księga jubileuszowa ofiarowana Profesorowi Waldemarowi Ceranowi, red. M. Kokoszko, M. J. Leszka, Łódź 2007, s. 317.

${ }^{14}$ Por. H. Burzyński, Struktura duszpasterstwa wojskowego $w$ kościelnym prawie powszechnym, Radom 1999, s. 13.

${ }_{15}$ Por. Histoire des Conciles, sous la direction de Ch. J. Hefele, H. Leclercq, t. 3/2, Paris 1910, S. 822 .

${ }^{16}$ Por. Kapelani wojskowi, w: Podręczna encyklopedya kościelna, oprac. ks. S. Gall, J. Niedzielski i in., t. 19-20, Warszawa 1910, s. 303-304; J. Radziszewski, $Z$ dziejów duszpasterstwa wojskowego..., s. 40.

${ }_{17}$ „Ut sacerdotes neque christianorum neque paganorum saguinem fundant [...]. Si sacerdotes sanguinem christianorum vel paganorum fuderint aut canonibus obviarent, sacerdotio 
zapisaną w kapitularzu powtórzył synod w Rheims z 1049 roku, przypominając kapłanom o zakazie używania broni ${ }^{18}$. Jasne postanowienie w tym zakresie wydał papież Innocenty III w bulli Ad Liberendam Terram Sanctam, w której domagał się, aby duchowni biorący udział w wojnie używali tylko „broni duchowej” i modlitwy, nie uczestnicząc w walce orężnej ${ }^{19}$. W okresie średniowiecza w wojskach niemieckich istniała instytucja kapelana polowego (Feldkapelan) pełniącego posługi religijne przy chorągwiach wojsk zaciężnych. Do obowiązków kapelanów należała również obsługa szpitali wojskowych i polowych ${ }^{20}$. W tym okresie znaczna część duchownych nie posiadała żadnego urzędu kościelnego ani stałego utrzymania, stąd bardzo często poszukiwali oni miejsca przy dworach możnowładców lub dowódców wojskowych, aby w ten sposób zostać kapelanem oddziału wojskowego lub kapelanem zamkowym ${ }^{21}$.

\section{Początki duszpasterstwa żołnierskiego w Polsce}

Obecność osób duchownych wśród wojska w Polsce prawdopodobnie wiąże się z przyjęciem chrześcijaństwa przez Mieszka I. Jednakże skąpa baza źródłowa nie pozwala na jednoznaczne potwierdzenie ich obecności ani też określenie zakresu posługi duszpasterskiej sprawowanej przy wojsku, a być może wyłącznie w obrębie drużyny książęcej. Więcej potwierdzonych w źródłach informacji dotyczących obecności duchownych w otoczeniu panującego księcia i towarzyszeniu mu podczas wypraw wojennych oraz sprawowania obowiązków kapelana znajdujemy w czasach Bolesława Chrobrego. Bowiem w kronice Thietmara, poświęconej m.in. opisom walk wojsk niemieckich z wojskami Bolesława Chrobrego jest zapis, w którym wspomniany kronikarz informuje o towarzyszącym księciu opacie Tunim.

priventur, quia deteriores sunt secularibus" (Karoli Magni Capitulare Primum 769 vel paullo post. Monumenta Gremanica Historia Leges, Sectio II, t. 1, s. 44-45; cyt. za: E. Nowak, Rys dziejów..., s. 4).

${ }_{18}$ Por. J. Manthey, Średniowieczne duszpasterstwo wojskowe, „Duszpasterz Polski Zagranicą” 9 (1958) nr 3, s. 268.

19 Por. Innocentius III, Bulla Ad Liberendam Terram Sanctam, w: Bullarium Romanum, t. 1, Lugduni 1673 , s. 88-89.

${ }^{20}$ Por. E. Nowak, Rys dziejów duszpasterstwa wojskowego w Polsce 968-1831, Warszawa 1932, S. 4 .

${ }^{21}$ Por. H. Burzyński, Struktura duszpasterstwa wojskowego..., s. 14. 
Z informacji zawartych w tej kronice dowiadujemy się, że opat Tuni towarzyszył Bolesławowi Chrobremu w co najmniej dwóch wyprawach (kampanii nadodrzańskiej 1015 r. i kijowskiej 1018 r. $)^{22}$. Nie mamy jednak żadnych informacji na temat sprawowania przez opata Tuniego posługi duszpasterskiej czy też kapelańskiej.

Można jednak domniemywać, że jakaś posługa kapelańska przy wojskach polskich była sprawowana. Zaświadcza o tym przekaz Thietmara o grzebaniu zwłok na pobojowisku w 1015 roku przez bp. Idziego. Biskup ten odprawił na polu bitwy modły za poległych i dokonał pochówku Niemców, czyniąc to za pełną aprobatą polskiego władcy ${ }^{23}$. Mniej wiarygodne przekazy na temat posługi kapelańskiej w czasach Bolesława Chrobrego to informacje podane nam przez Galla. Wynika to $\mathrm{z}$ tego, że kronika Anonima powstała blisko wiek później niż opisywane wydarzenia dotyczące epoki Chrobrego. Gall stwierdza tylko: „Episcopos quippe suosque capellanos in tanta veneratione retinebat, quod eis astantibus sedere non presumebat, nec eos aliter quam dominos appellabat" ${ }^{\text {"24 }}$. Jego przekazy nie pozwalają dokładnie prześledzić działań w ramach służby duszpasterskiej przy wojskach polskich w czasach następców Bolesława Chrobrego.

Wiarygodniejsze i pewniejsze w kwestii posługi kapelańskiej są dopiero informacje podawane przez Galla odnoszące się do panowania Bolesława Krzywoustego, ponieważ kronikarz wielokrotnie wymieniając osoby duchowne, używa terminu „kapelan”. Jako przykład może służyć opis uroczystości pogrzebowych po śmierci Władysława Hermana, kiedy abp Marcin przez pięć dni odprawiał w Płocku egzekwie „cum capellanis” ${ }^{25}$. Nie można też nie wspomnieć, że dedykacja księgi trzeciej zaczyna się od słów „Capellanis ducalibus venerandis alliisque bonis clericis per Poloniam memorandis $^{\prime 26}$. Wydaje się pewne, że rozgraniczenie dokonywane w nazwach funkcji osób duchownych jest zapisem w pełni świadomym i że używany termin „kapelan” oznacza być może kapelanów wojskowych bądź dworskich. Można też wysnuć przypuszczenie, że funkcje te były łączone. Potwierdzeniem

${ }_{22}$ Zob. Kronika Thietmara, z tekstu łacińskiego przetłumaczył, wstępem poprzedził i komentarzami opatrzył M. Z. Jedlicki, Poznań 1953, s. 497, 499, 623.

${ }_{23}$ Zob. Kronika Thietmara..., s. 499.

${ }^{24}$ Galli Anonymi, Cronica et gesta ducum sive principum Polonorum, wyd. K. Maleczyński, w: Monumenta Poloniae Historica [dalej: MPH], ser. II, t. 2, Kraków 1952, s. 26.

${ }^{25}$ Galli Anonymi, Cronica et gesta ducum sive principum Polonorum..., s. 88.

${ }^{26}$ Galli Anonymi, Cronica et gesta ducum sive principum Polonorum..., s. 120. 
w pełni świadomego używania przez Galla terminu „kapelan” jest opis postu przebłagalnego, jakiego dokonuje Bolesław za zbrodnię popełnioną na Zbigniewie. W kronice czytamy „abbates, presbiteri”, „In episcopis [...] in capellanis" ${ }^{27}$. Kronika Galla podaje nam również bezpośrednie informacje o posłudze duszpasterskiej przy wojskach polskich. W opisie wyprawy jesiennej na Pomorze w 1103 roku kronikarz stwierdza „Sexta die tandem sextaque feria communicati sunt eucharistia, refecti pariter victuo corporeo, Cholberg veniunt duetu sidereo. Precedenti nocte Belezlauus officium fieri sancte Marie constituit, quod postea usu pro devotione retinuit" ${ }^{28}$. Z powyższego przekazu można wnioskować, że w wyprawach wojennych towarzyszyli wojskom duchowni mający spełniać posługę kapelańską.

Należy sądzić, że Polscy królowie i książęta organizowali służbę duszpasterską przy swych wojskach wzorem innych władców chrześcijańskich ${ }^{29}$. W okresie panowania dynastii Piastów i Jagiellonów nie doszło do wykształcenia się stałej instytucji kapelana wojskowego, stąd opiekę duchową w wojsku pełnili kapelani królewscy, dworscy i obozowi nazywani również kaznodziejami obozowymi ${ }^{30}$. Inni duchowni posługiwali w wojsku tylko podczas działań wojennych. Po ich zakończeniu armia z wyjątkiem stałej drużyny królewskiej czy książęcej ulegała rozproszeniu i księża, podobnie jak rycerstwo, wracali do swoich codziennych zajęćc $c^{31}$. Nie było w tym okresie hierarchii duchowieństwa wojskowego, nie posiadało ono również odrębnej jurysdykcji, a całą władzę nad nim sprawował w obozie biskup kanclerz lub podkanclerzy. Ponieważ do 1507 roku urząd kanclerza i jego zastępcy pełnili z reguły duchowni, głównie biskupi, stąd też oni kierowali duchowieństwem obozowym w czasie wojny, pełniąc jednocześnie rolę quasi-naczelnego kapelana ${ }^{32}$. Duchowieństwo obozowe w czasie pokoju podlegało jurysdykcji biskupów diecezjalnych bądź właściwych przełożonych

${ }^{27}$ Galli Anonymi, Cronica et gesta ducum sive principum Polonorum..., s. 157, 159-16o.

${ }^{28}$ Galli Anonymi, Cronica et gesta ducum sive principum Polonorum..., s. 95.

${ }^{29}$ Por. D. Chodyniecki, Kapelani wojskowi w dziejach Polski do wybuchu II wojny światowej, „Saeculum Christianum” 4 (1997) nr 2, s. 106.

${ }^{30}$ Por. J. Odziemkowski, Historia Ordynariatu Polowego w Polsce, w: Przywrócenie Ordynariatu Polowego Wojska Polskiego, red. A. Kubicki, Warszawa 1991, s. 5.

${ }^{31}$ Por. J. Odziemkowski, S. Frątczak, Polskie duszpasterstwo wojskowe, Warszawa 1996, s. 13.

${ }^{32}$ Por. J. Humeński, Zarys historyczny duszpasterstwa wojskowego w Polsce, w: Wspomnienia wojenne księży kapelanów, red. J. Humeński, Warszawa 1967, s. 9-10. 
zakonnych $^{33}$. Potwierdza to m.in. postanowienie biskupa krakowskiego Tomasza Strzempińskiego, który na synodzie diecezjalnym w 1459 roku zabronił kapłanom udawania się na wyprawy wojenne ${ }^{34}$ celem odprawiania nabożeństw bez odpowiedniej zgody własnego ordynariusza. Jednocześnie prawodawca nakazał kapelanom pod karą ekskomuniki opuszczenie wojska w razie, gdyby dopuszczało się ono rabunków i grabieży ${ }^{35}$. W praktyce kapelani odprawiali dla żołnierzy msze święte, spowiadali, udzielali Komunii Świętej, głosili kazania, podnosili na duchu, dodawali otuchy. Za panowania Kazimierza Jagiellończyka (1447-1492) kapelani uzyskali na mocy dekretu papieża Mikołaja v z 23 grudnia 1447 roku przywilej korzystania z kaplicy polowej (altare portatile) ${ }^{36}$. Z kolei Grzegorz XıII zezwolił 22 kwietnia 1581 roku na odprawianie mszy świętej w obozach i namiotach. Był to pierwszy zachowany indult papieski dla księży posługujących w wojsku ${ }^{37}$.

Obszerniejsze wiadomości o polskim duszpasterstwie wojskowym znajdujemy u Jana Długosza. Według jego relacji wojskom dowodzonym przez Władysława Jagiełłę zawsze towarzyszyli kapelani. Opisując przygotowania do bitwy pod Grunwaldem stoczonej 15 lipca 1410 roku w ramach tzw. Wielkiej Wojny z Zakonem Krzyżackim ${ }^{38}$, Jan Długosz podkreślił, że przed rozpoczęciem walki w obozie polskim msze święte odprawili: ks. Bartosz z Kłobucka i proboszcz kaliski Jarosław ${ }^{39}$. Okolicznościowe nabożeństwa dziękczynne odprawiano również po zakończeniu bitwy, co za rządów Wła-

${ }^{33}$ Por. H. Burzyński, Struktura duszpasterstwa wojskowego..., s. 15.

${ }^{34}$ Należy podkreślić, że postanowienia synodu zostały ogłoszone w okresie tzw. wojny trzynastoletniej (1454-1466), a więc w czasie wzmożonych działań wojennych, zakończonych podpisaniem 19 października 1466 roku tzw. II pokoju toruńskiego. Por. M. Biskup, Trzynastoletnia wojna z Zakonem Krzyżackim 1454-1466, Warszawa 1967, s. 695; K. Baczkowski, Dzieje Polski późnośredniowiecznej 1370-1506, Kraków 1999, s. 224.

35 Zob. Statut biskupa krakowskiego Tomasza Strzempińskiego z 9.05.1459 r. Przepisy dla kapelanów wojskowych w czasie wojny, w: U. Heyzmann, Starodawne prawa polskiego pomniki, t. 4, Kraków 1875, s. 116.

${ }^{36}$ Por. A. Theiner, Vetera monumenta Poloniae et Lithuaniae genitumque finitimarum historiam illustrantia, t. 2, Roma 1861, s. $55-56$.

37 Por. H. Burzyński, Struktura duszpasterstwa wojskowego..., s. 39; J. Humeński, Zarys historyczny duszpasterstwa wojskowego w Polsce, s. 12. Ksiądz Julian Humeński błędnie podał imię papieża, chodzi bowiem o Grzegorza XIII, a nie Grzegorza III.

${ }^{38}$ Por. S. Kuczyński, Wielka Wojna z Zakonem Krzyżackim w latach 1409-1411, Warszawa 1960, s. 479. Wojna ta zakończyła się podpisaniem 1 lutego 1411 roku tzw. I pokoju toruńskiego.

39 Zob. J. Długosz, Roczniki, czyli Kroniki sławnego Królestwa Polskiego, Księga x/xı, Warszawa 1982, s. 76, 100, 142 . 
dysława Jagiełły (1385-1434) stało się zwyczajem ${ }^{40}$. Zgodnie ze wspomnianą bullą Innocentego III Ad Liberendam Terram Sanctam duchowni nie mogli osobiście walczyć. Zasada ta nie była jednak do końca respektowana, czego dowodem może być m.in. wydany w 1347 roku statut wiślicki nakładający na duchownych posiadających dobra dziedziczne obowiązek wzięcia udziału w pospolitym ruszeniu ${ }^{41}$. Zwolnienie księży od osobistej służby wojskowej nastąpiło w $1497 \mathrm{roku}^{42}$. Wśród kapelanów obozowych początkowo najwięcej przedstawicieli mieli dominikanie i franciszkanie, rzadziej księża diecezjalni. W XVI wieku w skład korpusu księży kapelanów weszło wielu przedstawicieli wywodzących się z Towarzystwa Jezusowego.

Dla przykładu kapelanem Leszka Czarnego był o. Idzi należący do dominikanów, podobnie jak o. Eliasz będący kapelanem Władysława Jagiełły. Kazimierz Jagiellończyk (1447-1492) korzystał z posługi sakramentalnej dominikanów: o. Stefana i o. Jana oraz kapelanów nadwornych, którymi byli Albert z Soszna, Mikołaj z Piotrkowa, a także pleban Andrzej z Osiecka. Na dworze Jana Olbrachta (1493-1501) i Aleksandra Jagiellończyka (15011506) służyli m.in. dominikanie: Walenty Kucharski i Mikołaj Korczak ${ }^{43}$. Wśród kapelanów Zygmunta I Starego (1506-1548) na szczególną uwagę zasługuje Wit Albanus, który był przy ostatnich chwilach życia monarchy. Rachunki królewskie wystawiane za panowania Zygmunta I Starego i Zygmunta II Augusta (1548-1572) zawierają nazwiska kilkunastu kapelanów nadwornych, m.in. Jana Wirzbkowskiego, Marcina Podgórskiego i Adama z Bełczyc ${ }^{44}$.

\section{Ukonstytuowanie stałego duszpasterstwa żołnierskiego}

Wraz z rozwojem organizacji wojskowej rozpoczęły się również kształtować formalno-prawne struktury duszpasterstwa wojskowego wymagające wprowadzenia instytucji stałego kapelana. Ponieważ historia wojskowości

$4^{\circ}$ Por. E. Nowak, Rys dziejów..., s. 11.

${ }^{41}$ Pospolite ruszenie stanowiło ogół ludności kraju powoływanej pod broń w czasie wojny. W dawnej Polsce była to najstarsza forma organizacji zbrojnej. Por. Wojsko, wojna, broń. Leksykon $P W N$, red. M. Kamler, Warszawa 2001, s. 225.

${ }^{42}$ Por. K. Klupa, Katolickie duszpasterstwo wojskowe w Polsce do 1831 roku, „Poglądy i Doświadczenia" 1999 nr 113, s. 117.

${ }^{43}$ Por. J. Humeński, Zarys historyczny duszpasterstwa wojskowego w Polsce, s. 10-11.

${ }^{44}$ Por. D. Chodyniecki, Kapelani wojskowi..., s. 108. 
nie znała wojsk stałych, stąd początkowo trudno było o wykształcenie się instytucji stałego kapelana. Postulat wprowadzenia stałych kapelanów w armii wysunął papież Juliusz II w specjalnej bulli wydanej w 1511 roku. Eksplikując potrzebę spełniania posług religijnych w wojsku, określił kapelanów terminami: cappellani banderiae lub cappellani castrorum ${ }^{45}$. Rozwiązanie kwestii postulowanej przez Juliusza II przyniosła wojna trzydziestoletnia (1618-1648), w czasie której powstała organizacja wojsk stałych, a także instytucja stałych kapelanów na czas pokoju ${ }^{46}$. Wyjęcie kapelanów wojskowych spod jurysdykcji biskupów diecezjalnych zarezerwowane było Stolicy Apostolskiej.

Proces organizacji stałego duszpasterstwa wojskowego był też przedmiotem artykułów wojskowych króla szwedzkiego Gustawa in Adolfa ${ }^{47}$. Przyczynkiem do rozwiązania tej kwestii było breve papieża Innocentego x Cum sicut maiestatis z 26 września 1645 roku, nadające specjalnym prałatom wiele kompetencji w zakresie posługi religijnej w wojsku. Prałat ten wyposażony był w odpowiednie uprawnienia w stosunku do osób wojskowych ${ }^{48}$. Podobne przywileje posiadał tzw. Wielki Jałmużnik Królewski noszący tytuł prałata i ustanowiony na podobieństwo pasterza powierzonej grupy osób ${ }^{49}$. Innocenty $\mathrm{x}$ na mocy tego dokumentu udzielił wszelkich jurysdykcji (plenipotencji) kapelanom wojskowym Królestwa Hiszpanii, w sytuacji, gdyby zaistniała trudność odniesienia się do Stolicy Apostolskiej i do biskupa miejsca z powodu działań wojennych ${ }^{50}$. Kapelani we wszystkich państwach początkowo podlegali biskupom diecezjalnym, na których terenie toczyła się wojna ${ }^{51}$. W krajach niekatolickich kapelani korzystali ze specjalnych

${ }^{45}$ Por. H. Burzyński, Struktura duszpasterstwa wojskowego..., s. 14.

${ }^{46}$ Por. J. Freisen, Das Militär-Kirchenrecht in Heer und Marine des Deutschen Reiches nebst Darstellung des ausserdeutschen Militärkirchenwesens, Paderborn 1913, s. 4.

47 Zob. J. Langhauser, Das Militarkirchenwesen im kurbranderburgischen und Königlich preussischen Heer. Seine Entwickelung und derzeitige Gestalt, Metz 1912, s. 3.

${ }^{48}$ Por. W. Góralski, W. Adamczewski, Konkordat między Stolica Apostolska a Rzeczapospolita Polska z 28 lipca 1993 r., Płock 1994, s. 89. Autorzy podkreślają, że „duszpasterstwo osób wojskowych, stanowiące od dawna doniosły przedmiot troski Kościoła katolickiego, przybrało $\mathrm{z}$ biegiem czasu formalne struktury prawne, poczynając od breve papieża Innocentego $\mathrm{x}$ Cum sicut maiestatis z 26.09.1645 r.".

49 Por. B. Gantin, Per una piú efficace cura spirituale dei militari, „L'Osservatore Romano” (wydanie włoskie) 5-6.05.1986, nr 106, s. 1 i 6.

${ }^{50}$ Por. H. Burzyński, Struktura duszpasterstwa wojskowego..., s. 14.

${ }^{51}$ Por. H. Burzyński, Struktura duszpasterstwa wojskowego..., s. 15. 
przywilejów udzielanych im przez Stolicę Apostolską lub nuncjusza apostolskiego ${ }^{52}$.

W Polsce znaczącym przyczynkiem do powołania stałego duszpasterstwa żołnierskiego było utworzenie przez Zygmunta II Augusta w 1562 roku tzw. wojska kwarcianego, które miało być finansowane z czwartej części dochodów królewskich ${ }^{53}$. Jednocześnie powołano osobny skarbiec celem finansowania stałego wojska przeznaczonego do ochrony granic południowo-wschodnich. Liczące początkowo 4 tys., a następnie 6 tys. ludzi wojsko kwarciane zostało osadzone na Podolu i Ukrainie. W najmowanych wojskach zaciężnych rekrutowani przez kapitana kapelani pochodzili z narodowości, z jakiej składały się chorągwie czy pułki ${ }^{54}$.

Drugim, równie ważnym przyczynkiem było wyodrębnienie się w XVI wieku w Polsce instytucji hetmańskiej stanowiącej jakby stałe dowództwo sił zbrojnych Rzeczypospolitej. Praktycznie hetmani przejęli z rąk króla władzę nad wojskiem. Armia zaciężna podlegała hetmanowi wielkiemu, którego zastępował hetman polny. Do kompetencji hetmana należała regulacja spraw organizacyjnych i porządkowych, przedstawianych w tzw. artykułach hetmańskich, w których „znajdujemy przepisy i jak gdyby zaczątki organizacji duszpasterstwa" ${ }^{55}$. Szczególne zasługi dla organizacji stałej opieki duszpasterskiej w wojsku ma jeden z największych polskich teoretyków wojskowych, hetman Jan Tarnowski ${ }^{56}$. W swoim najsławniejszym dziele zatytułowanym Consilium rationis bellicae napisał: „kaznodzieja dobry, na którym też wiele należy, aby ludziom serca dodawał, a zwłaszcza, iż w każdym wojszcze musi wiele ludzi być ex vulgo et in proverbio dicitur (zludu, a przysłowie mówi), a prawda jest quod vulgas plus vatibus quam ducibus regitur (ze ludem

${ }^{52}$ Por. H. Burzyński, Struktura duszpasterstwa wojskowego..., s. 15.

${ }_{53}$ Zob. Konstytucje Sejmu Piotrkowskiego zaczętego roku 1562 a dokończonego 1563, w: Volumina Legum. Przedruk Zbioru Praw staraniem xx Pijarów, t. 2, Petersburg 1859, s. 17; T. Korzon, Dzieje wojen i wojskowości w Polsce, t. 1, Epoka przedrozbiorowa, Lwów-Kraków-Warszawa 1923, s. 368-369; D. Chodyniecki, Kapelani wojskowi..., s. 109; Zastanawiające jest, dlaczego Humeński datuje powstanie wojska kwarcianego na 1602 rok. Por. J. Humeński, Zarys historyczny duszpasterstwa wojskowego w Polsce, s. 11.

${ }_{54}$ Por. E. Nowak, Rys dziejów..., s. 18.

55 E. Nowak, Rys dziejów..., s. 18.

${ }^{56}$ Zob. szerzej: K. Olejnik, Hetman Jan Tarnowski i jego miejsce w dziejach wojskowości polskiej, w: Jan Tarnowski -hetman wielki koronny, Tarnów 1999; Z. Spieralski, Jan Tarnowski 1488-1561, Warszawa 1977; P. Jaworski, Hetman Jan Tarnowski w dziejach wojskowości polskiej, „Wojsko i Wychowanie” $2003 \mathrm{nr}$ 4, s. 17-24. 
kieruja $w$ większym stopniu prorocy, niż wodzowie), może być roztropny, umiejętny, a wymowny kaznodzieja, gdy rozwiedzie, iże to walka sprawiedliwa, acz by Pan Bóg na kogo śmierć dopuścił, iże się ma czego nadziewać innego, jeno zbawienia swego, inne perswazje zbawienne czynić może, czym by ludzie chciwi ku bojowi za jego napominaniem byli"s7. Autor będący zwolennikiem takiej organizacji wojska, które w każdej chwili gotowe będzie odeprzeć najazd wroga ${ }^{58}$, przedstawia potrzebę posługi kapelanów w wojsku, opowiadając się za stałym duszpasterstwem wojskowym. Jan Tarnowski nakreślił również cechy dobrego kapelana, który jego zdaniem powinien być wysoko wykształconym i wymownym kaznodzieją, aby móc uzasadnić konieczność walki oraz być pomostem między korpusem oficerskim a szeregowcami. Zasady głoszone przez hetmana Jana Tarnowskiego wywarły wielki wpływ na dalszy rozwój duszpasterstwa wojskowego, dały bowiem nie tylko jego uzasadnienie, ale także impuls do zadbania o moralność w wojsku.

Próbę odrębnej organizacji duszpasterstwa wojskowego przedstawił kapelan tzw. „lisowczyków” ks. Wojciech Dembołęckii" ${ }^{59}$ który nakreślił pewną strukturę pracy kapelanów wojskowych. Z jego artykułów wynika, że nad duchownymi pracującymi w wojsku byli ustanowieni starsi (superiorzy), którzy czuwali nad właściwym postępowaniem pozostałych kapelanów, sprawując nad nimi władzę sądowniczą. Mogli oni powoływać nowych kapelanów, a także usuwać tych, którzy wykazywali się brakiem zdyscyplinowania i odpowiedzialności. Starszy kapelan pełnił kompetencje sądu I instancji dla duchowieństwa wojskowego, które niezadowolone z jego werdyktu mogło odwołać się do sądu II instancji - jego prerogatywy posiadał najbliższy ordynariusz diecezjalny ${ }^{60}$. Na podstawie artykułów elearskich ks. Wojciecha Dembołęckiego możemy przypuszczalnie odtworzyć sytuację kapelanów wojskowych w Polsce, kierując się chociażby artykułem xxxI odwołującym się do wcześniejszych artykułów hetmańskich. Należy jednak podkreślić, że autor był kapelanem „lisowczyków” na służbie u cesarza Ferdynanda II $(1619-1637)^{61}$. Stąd konieczne jest podkreślenie, że oddział

\footnotetext{
57 J. Tarnowski, Consilium rationis bellicae, Warszawa 1987, s. 47.

${ }^{58}$ Por. W. Bogatyński, Hetman Tarnowski: 1488-1561, Kraków 1913, s. 169-171.

59 Swoje postulaty ks. Wojciech Dembołęcki przedstawił w książce pt. Przewagi elearów polskich, co ich niegdyś lisowczykami zwano 1619-1623, Puławy 1830.

${ }^{60}$ Por. E. Nowak, Rys dziejów..., s. 24-27.

${ }^{61}$ Por. H. Wereszycki, Historia Austrii, Warszawa-Wrocław 1972, s. 95; H. Wisner, Lisowczycy, Warszawa 1976, s. 345.
} 
ten funkcjonował w myśl przepisów panujących w Austrii, gdzie w 1534 roku Stolica Apostolska mianowała na czas wojny wikariuszów polowych i kapelanów sztabu generalnego ${ }^{62}$. Z tej racji „lisowczycy” będący wojskiem cesarskim podlegali bezpośrednio naczelnemu kapelanowi wojsk cesarskich, który na mocy delegacji papieskiej posiadał nad nimi władzę.

W tym okresie wśród żołnierzy polskich spotykamy kapelanów rekrutujących się głównie z zakonów, co oznaczało wyłączenie ich spod władzy ordynariuszów diecezjalnych. Ich praca w wojsku była traktowana jako tzw. ruchoma misja. Kompetentna władza zakonna wyznaczała jednego z pracujących w wojsku kapelanów na tzw. superiora misji ${ }^{63}$. Kapelani wojskowi będący kapłanami diecezjalnymi nadal podlegali biskupom diecezji, na terenie których toczyły się walki. Do obowiązków kapelana należała troska o paramenty liturgiczne, a także o tzw. ołtarzyki polowe, często zdobione wizerunkami Matki Bożej oraz patronów polski: św. Wojciecha i św. Stanisława, biskupa krakowskiego. Pieniądze potrzebne na wyposażenie liturgiczne kapelan otrzymywał z kasy królewskiej lub hetmańskiej. Kapelanowi pomagał specjalnie zatrudniony organista lub kapelmistrz, który często prowadził także chór. Otwarty problem stanowiło nadal uposażenie kapelanów wojskowych. Nie było ono stałe, gdyż nie było stałego duszpasterstwa wojskowego. Kapelani hetmanów i możnowładców należeli do urzędników dworskich i otrzymywali wynagrodzenie stosownie do umowy, będąc na ich całkowitym utrzymaniu zarówno na dworze, jak i w obozie. Pod koniec panowania dynastii Jagiellonów najwięcej otrzymywał kaznodzieja królewski $^{64}$, którego żołd wynosił 416 zł rocznie, najmniej zaś zakrystian, który jako pomocnik kapelana otrzymywał 20 zł rocznie. W 1609 roku w czasie ustanowienia trybunałów skarbowych: koronnego Radomsku i litewskiego

${ }^{62}$ Por. E. Nowak, Rys dziejów..., s. 26. Przedstawiając sytuację kapelanów wojskowych w Austrii, należy zauważyć, że na prośbę cesarza Ferdynanda III papież Urban viı na mocy brewe wydanego 18 września 1643 roku nadał spowiednikowi cesarskiemu władzę biskupią nad wszystkimi osobami będącymi w wojsku. Była to pierwsza w dziejach Kościoła egzempcja osób wojskowych spod władzy ordynariuszów diecezjalnych. Przywilej ten miał zastosowanie tylko w czasie wojny. Por. C. Ham, Von den Anfängen der Militärseelsorge bis zur Liquidierung des Apostolischen Feldvikariates im Jahr 1918, w: R. H. Gröger, C. Ham, A. Sammer, Zwischen Himmel und Erde. Militärseelsorge in Österreich, Graz-Wien-Köln 2001, s. 22-23.

${ }^{63}$ Por. E. Nowak, Rys dziejów..., s. 26; D. Chodyniecki, Kapelani wojskowi..., s. 111.

${ }^{64}$ Kapelan (kaznodzieja) królewski miał do pomocy wikariuszy i kapelanów nadwornych. Por. Z. Góralski, Kapelan królewski, w: Encyklopedia urzędów i godności w dawnej Polsce, Warszawa 2000, s. 56-57. 
w Wilnie sejm wydał specjalną uchwałę normującą uposażenie żołnierzy. W myśl tego postanowienia kapelan pobierał $40 \mathrm{zl}$ kwartalnie ${ }^{65}$. W XVII wieku wskutek dewaluacji polskiego złotego wynagrodzenie w wojsku uległo nominalnemu wzrostowi. Za Jana III Sobieskiego kapelan otrzymywał 500 zł rocznie.

Widocznym przejawem szerokiej działalności polskich kapelanów wojskowych były liczne modlitewniki żołnierskie ${ }^{66}$. Pierwszy z nich ukazał się już w 1589 roku i nosił tytuł Officium Militare ${ }^{67}$. Jego autorem był nadworny kaznodzieja i kapelan Stefana Batorego ks. Stanisław Sokołowski ${ }^{68}$. Następny modlitewnik noszący tytuł Żołnierskie nabożeństwo - modlitwy i przykłady do tego stanu służące został wydany 11 lutego 1606 roku przez ks. Piotra Skarge ${ }^{69}$, nazywającego siebie „duchownym od dusz żołnierskich”. Jako kapelan dworski Skarga wygłosił wiele kazań, w których szczególnie podkreślał konieczność jedności religijnej państwa, znaczenie chrześcijańskiej moralności oraz wymóg reform państwa polskiego pod groźbą jego

${ }^{65}$ Por. E. Nowak, Rys dziejów..., s. 38. Dla porównania żołnierz wojsk kwarcianych dostawał w myśl decyzji sejmu 20 zł kwartalnie, zaś żołnierz ekstraordynaryjny 30 zł na kwartał. Por. Konstytucye Sejmu Wielkiego Koronnego w Warszawie Roku Pańskiego 1609, w: Volumina Legum, s. 463 .

${ }^{66}$ Zob. szerzej: M. Lenart, Miles pius et iustus. Żołnierz chrześcijański katolickiej wiary w kulturze i piśmiennictwie dawnej Rzeczypospolitej (XVI-XVIII w.), Łódź 2009.

${ }^{67}$ Według Humeńskiego modlitewnik ten nie zachował się do dzisiejszych czasów. Por. J. Humeński, Modlitewniki żołnierskie, „Przegląd Powszechny” 4 (1991), s. 132. Sprawa pierwszego polskiego modlitewnika dla żołnierzy jest jednak problematyczna, ponieważ autorzy wskazujący, że pierwszym modlitewnikiem był Officium Militare (por. J. Humeński, Modlitewniki..., s. 132; E. Nowak, Rys dziejów..., s. 32; H. Burzyński, Struktura duszpasterstwa wojskowego..., s. 39) nie wspominają o wydanej w 1583 roku we Lwowie Harfie duchowej Marcina Laterny. Z kolei Dariusz Chodyniecki uważa, że pierwsza książeczka do nabożeństw dla żołnierzy ukazała się w 1604 roku i prawdopodobnie została napisana przez Marcina z Bydgoszczy. Por. D. Chodyniecki, Kapelani wojskowi..., s. 108.

${ }^{68}$ Ksiądz Sokołowski był także autorem traktatów dydaktycznych o charakterze moralno-społecznym, np. Partitiones ecclesiastice i De ratione studii.

${ }^{69}$ Piotr Skarga należał do Towarzystwa Jezusowego i początkowo znany był jako Piotr Pawęski. W styczniu 1588 roku został powołany przez Zygmunta III Wazę na dwór królewski w charakterze głównego kaznodziei. Por. C. Lechicki, Jezuici i Skarga na dworze Zygmunta III, Lwów 1929, s. 17. Odrębny urząd głównego kaznodziei królewskiego został utworzony przez Zygmunta III w 1588 roku. Por. S. Obirek, Jezuici na dworach Batorego i Wazów 1580-1668. Wpływ kapelanów dworskich i wychowawców książąt na postawy panujących i politykę państwa, Kraków 1996, s. 31. 
upadku $^{70}$. Kolejnym wydawcą modlitewnika przeznaczonego dla żołnierzy był również jezuita, ks. Mateusz Bembus. Jego książeczka zatytułowana Bellator Christianus zawierała zbiór zasad i wskazówek duchownych dla dowódców wojskowych, szereg rad dotyczących strategii wojskowej oraz zbiór modlitw. W wydanym w 1617 roku modlitewniku jego autor domagał się również ustanowienia stałych etatów kapelanów obozowych ${ }^{71}$, co było odzwierciedleniem dążenia do ustanowienia stałej służby kapelanów w wojsku. Bembus dążył do tego, aby oddziały stacjonujące w obozach musiały mieć ustalone godziny modlitw ${ }^{72}$. Zalecał również, aby na chorągwiach zawsze umieszczano krzyż święty ${ }^{73}$.

Okres poprzedzający wprowadzenie instytucji stałego kapelana wojskowego charakteryzował się obecnością wielu znamienitych kapelanów obozowych, których ofiarna służba na stałe zapisała się w historii polskiego oręża. Obok wymienianych już wcześniej Piotra Skargi i Mateusza Bembusa na podkreślenie zasługuje ks. Marcin Laterna, który zasłynął z opracowania w 1583 roku książeczki do nabożeństwa zatytułowanej Harfa duchowna oraz $\mathrm{z}$ udziału w wyprawach wojennych Stefana Batorego. 30 września 1598 roku został utopiony w Szwecji przez żołnierzy Karola Ix Sudermańskiego ${ }^{74}$, którzy nie mogli znieść odwagi, z jaką polski kapelan bronił wiary katolickiej ${ }^{75}$. Wielu kapelanów poległo na polach bitew, do końca towarzysząc walczącemu żołnierzowi polskiemu. W 1612 roku podczas mołdawskiej wyprawy Stefana Potockiego zginął w boju o. Stanisław Olbrycjusz. Sześć lat później podczas walki z Tatarami zginął pełniący funkcję kapelana o. Samuel Zagórski. W 1620 roku podczas wyprawy hetmana Stanisława Żółkiewskiego zakończonej klęską pod Cecorą ${ }^{76}$ zginęli karmelici: Klemens Ilnicki, Dionizy

$7^{0}$ Por. J. Tazbir, Piotr Skarga. Szermierz kontrreformacji, Warszawa 1972, s. 122. Postulaty przedstawiane w kazaniach przez Piotra Skargę zostały wyakcentowane w wydanych w 1597 roku Kazaniach sejmowych.

${ }^{71}$ Por. J. Humeński, Modlitewniki..., s. 132.

${ }^{72}$ Potrzebę wprowadzenia stałych godzin modlitw w wojsku przedstawił również Andrzej Maksymilian Fredro w dziełach: Przysłowia mów potocznych, albo przestrogi obyczajowe, radne, wojenne i Militarium seu axiomatum belli.

${ }_{73}$ Por. J. Odziemkowski, S. Z. Frątczak, Polskie duszpasterstwo wojskowe..., s. 16.

${ }^{74}$ Por. I. Anderson, Dzieje Szwecji, tłum. P. Piekarczyk, Warszawa 1967, s. 131-149; A. Kersten, Historia Szwecji, Warszawa 1973, s. 438.

75 Por. K. Kotula, Ks. Marcin Laterna TJ. Kapelan obozowy - męczennik za wiarę (1552-1598), Warszawa 1938, s. 6-10.

${ }^{76}$ Zob. R. Majewski, Cecora 1620, Warszawa 1970. 
Kosteński i Fabian Porowicz. W walkach pod Chocimiem poniósł śmierć jezuita ks. Bartłomiej Wolboriusz ${ }^{77}$. Ponadto $\mathrm{z}$ posługi religijnej w wojsku zasłynęli kapelani Stefana Batorego ${ }^{78}$ : Stanisław Sokołowski, Piotr Lilia i Antoni Arias, a także Walenty Fabricuis i Stanisław Pstrokoński będący nadwornymi kaznodziejami na dworze Zygmunta III, który oprócz opieki nad wojskiem i otoczeniem dworu powierzył także księżom jezuitom nadzór nad wychowaniem i edukacją dzieci królewskich ${ }^{79}$. Za panowania Władysława IV Wazy zasłynęli: Maciej Kazimierz Sarbiewski oraz Fabian Birkowski, który w 1607 roku został mianowany przez Zygmunta III nadwornym kaznodzieją jego syna Władysława, głosząc mu słowo Boże w latach 1611-1634. Birkowski zaznał trudów wojennych, uczestnicząc w bitwie pod Chocimiem w 1621 $\mathrm{roku}^{80}$ oraz w kampanii wołoskiej i moskiewskiej ${ }^{81}$. Do znanych kapelanów obozowych należy także zaliczyć o. Stanisława Papczyńskiego ${ }^{82}$ i papieskiego dyplomatę o. Marka D’Aviano ${ }^{83}$, którzy brali udział w zwycięstwie wojsk Jana III Sobieskiego 12 września 1683 roku pod Wiedniem nad armią turecką dowodzoną przez wielkiego wezyra Kara Mustafę. Przed rozpoczęciem bitwy kapelani ci odprawili msze święte ${ }^{84}$, a następnie udzielili walczącym błogosławieństwa ${ }^{85}$. Przez całą bitwę o. Marek stał na wzgórzu, trzymając

77 Por. J. Odziemkowski, S. Z. Frątczak, Polskie duszpasterstwo wojskowe..., s. 15.

${ }^{78}$ Humeński wspomina o sprowadzeniu przez Stefana Batorego do Polski kapelanów węgierskich wojsk zaciężnych. Por. J. Humeński, Zarys historyczny duszpasterstwa wojskowego $w$ Polsce, s. 17.

79 Por. U. Augustyniak, Wazowie i „królowie rodacy”. Studium władzy królewskiej w Rzeczypospolitej XVII wieku, Warszawa 1999, s. 153.

${ }^{80}$ Por. J. Pajewski, Buńczuk i koncerz. Z dziejów wojen polsko-tureckich, Warszawa 1960, s. $86-104$.

${ }^{81}$ Por. S. M. Kałdon, O. Fabian Birkowski op (1566-9.12.1636) jako kaznodzieja, „Premislia Christiana" 9 (2001), s. 193.

${ }^{82}$ Zob. J. Kozielewski, Wielki przyjaciel żołnierza, kapelan i spowiednik króla Jana Trzeciego ks. Stanisław Papczyński, „Kwartalnik Poświęcony Sprawom Katolickiego Duszpasterstwa Wojskowego w Polsce" 3 (1933), s. 13-19.

${ }^{83}$ Ojciec Marek D’Aviano (Carlo Cristofori) jako wysłannik papieża Innocentego xı gorąco zachęcał do idei walki z Turcją. Por. J. Wimmer, Wiedeń 1683. Dzieje kampanii i bitwy, Warszawa 1983 , s. 145 i 446.

${ }^{84}$ Wówczas nie było tzw. koncelebry.

${ }^{85}$ Por. F. Röhrig, P. Markus von Aviano und sein Einsatz für die Befreiung Wiens, w: Die Bedeutung des P. Markus von Aviano für Europa, Hrsg. J. Mikrut, Wien 2003, s. 170; J. Wimmer, Wiedeń 1683. Dzieje kampanii i bitwy, Warszawa 1983, s. 317. 
uniesiony wysoko krzyż Jezusa Chrystusa ${ }^{86}$, symbolizując tym samym nie tylko obecność kapłana wśród wojsk dowodzonych przez polskiego władcę, ale także znaczenie i wymowę bitwy, której wynik miał szczególne znaczenie dla całego Kościoła katolickiego. Po zakończeniu bitwy odśpiewano dziękczynne Te Deum laudamus ${ }^{87}$. Marek D’Aviano i o. Stanisław Papczyński ${ }^{88}$ zamykają długi poczet kapelanów obozowych przed nastaniem regularnej służby duszpasterskiej ${ }^{89}$.

W połowie XVII wieku nasiliły się żądania utworzenia przy wojsku stałych etatów kapelańskich. Jednym z postulujących był Andrzej Maksymilian Fredro, który w wydanym w dziele Potrzebne konsyderacye około porządku woiennego i pospolitego ruszenia... z przydatkiem sporzadzenia ekonomii woiennei i sposobu, iakoby woyska Rzeczypospolitey mogły być w dobrym porządku zatrzymane postawił wyraźny wniosek, aby każda chorągiew konna i piesza posiadała swojego kapelana, gdyż, jego zdaniem, jest on w wojsku bardziej potrzebny niż orkiestra ${ }^{90}$. Ten sam autor domagał się w swoim drugim dziele zatytułowanym Militarium seu axiomatum belli utworzenia stanowiska naczelnego kapelana obozowego posiadającego zwierzchnią władzę nad innymi kapelanami ${ }^{91}$.

Stałe duszpasterstwo wojskowe, jako jedno z pierwszych państw w Europie Polska wprowadziła do swej armii na sejmie warszawskim w 1690 roku $^{92}$, ustanawiając 36 etatowych kapelanów ${ }^{93}$. Według Edmunda Nowaka

${ }^{86}$ Por. K. Tuszyński, Legat papieski-kapelan Wiedeńskiej Odsieczy o. Marek D’Aviano, „Nasza Służba" 1 (1992) nr 7, s. 3.

${ }^{87}$ Por. A. Dobroński, A. Woltanowski, Diariusz oblężenia Wiednia, „Mówią Wieki” 1984 nr 2, s. 5 .

${ }^{88}$ O. Stanisław Papczyński jest założycielem Zgromadzenia Księży Marianów i Zgromadzenia Sług Niepokalanej Dziewicy.

${ }^{89}$ Por. D. Chodyniecki, Kapelani wojskowi..., s. 113.

$9^{\circ}$ A. M. Fredro, Potrzebne konsyderacye około porządku woiennego i pospolitego ruszenia [...] z przydatkiem sporządzenia ekonomii woiennei i sposobu, iakoby woyska Rzeczypospolitey mogły być $w$ dobrym porządku zatrzymane, Warszawa 1789, p. 15, s. 20. Pierwsze wydanie tej książki miało miejsce prawdopodobnie w Lipsku w 1675 roku. Por. E. Nowak, Rys dziejów..., s. 22-23; J. Humeński, Zarys historyczny duszpasterstwa wojskowego w Polsce, s. 12.

${ }^{91}$ Por. A. M. Fredro, Militarium seu axiomatum belli, Lipsk 1757, s. 127. Cyt. za: E. Nowak, Rys dziejów..., s. 29.

${ }_{92} 16$ stycznia - 6 maja 1690 roku.

${ }_{93}$ Por. T. Sokołowski, Usytuowanie i funkcjonowanie duszpasterstwa w Wojsku Polskim, Toruń 1996, s. 11. Por. O. Laskowski, Wychowanie wojskowe Jana Sobieskiego, Warszawa 1922, S. $45-49$. 
w wymienionych przez konstytucję sejmową chorągwiach husarskich, petyhorskich, tatarskich i kozackich nie było kapelanów ze względu na niewielką liczbę żołnierzy wchodzących w skład tych oddziałów ${ }^{94}$. Recepcja uchwał sejmu warszawskiego przebiegała jednak bardzo wolno, nie wprowadzono hierarchii duchowieństwa wojskowego, powolnie regulowano kwestię uposażenia kapelanów mającego wynosić 500 zł rocznie. Impuls do określenia pozycji kapelanów i ich podległości dał dopiero jezuita Wojciech Tylkowski, który w książce De bono tam In pace quam bello, sive pars philosophiae moralis in duas divisa partes postulował wprowadzenie w wojsku odrębnej hierarchii duchownej. Autor ukazał także modele organizacyjne zachodnich wojsk, wspominając między innymi o wymaganiach hrabiego Jana Baptysty Galeberta w zakresie zatrudniania w wojsku osób potrzebnych do spełniania odpowiednich czynności, w tym także posług religijnych oraz o konkretnych miejscach kapelanów w ogólnym etacie wojska ${ }^{95}$.

\section{Podsumowanie}

Kościół zawsze z niezwykłą dbałością starał się o zapewnienie żołnierzom, stosownie do różnych okoliczności, duchowej opieki. Żołnierze stanowią bowiem określoną grupę społeczną i „ze względu na szczególne warunki życia”, wchodząc na stałe w skład sił zbrojnych z własnej woli lub też na mocy prawa powołani do nich na określony czas, potrzebują konkretnej i specyficznej opieki duszpasterskiej ${ }^{96}$.

Oprócz prowadzenia duszpasterstwa ogólnego Kościół bardzo mocno angażuje się w różnego rodzaju duszpasterstwa specjalistyczne, do których zaliczamy także duszpasterstwo wojskowe cieszące się swoistego rodzaju odrębnością i autonomią prawną. Przytoczone na wstępie słowa ojca świętego Jana Pawła II z wydanej 21 kwietnia 1986 roku Konstytucji apostolskiej

\footnotetext{
${ }^{94}$ Zob. E. Nowak, Rys dziejów..., s. 72.

95 W. Tylkowski, De bono tam in pace quam bello sive pars philosophiae moralis duas divisa partes, Wyd. Joannes Jacobus, Oliwa 1691, s. 178-181 (pars II, caput I, $₫$ xIV De officialibus).

${ }^{96}$ Jan Paweł II, Konstytucja apostolska Spirituali Militum Curae na temat ordynariatów wojskowych, w: Schematyzm Ordynariatu Polowego Wojska Polskiego 200o, Warszawa 200o, s. 535; zob. Ioannes Paulus II, Constitutio apostolica qua nova Canonici ordinatio pro Spirituali Militum Curae datur, „Acta Apostolicae Sedis” 78 (1986), s. 481-486.
} 
Spirituali Militum Curae o ordynariatach wojskowych ${ }^{97}$ są świadectwem ogromnej troski Kościoła o zapewnienie opieki religijnej w siłach zbrojnych poszczególnych państw.

Historia duszpasterstwa żołnierskiego w Polsce jest integralnie związana z historią państwa i jego aktualną sytuacją polityczną. Głębokie przemiany społeczno-polityczne zachodzące w latach 1989-1990 stworzyły warunki sprzyjające przywróceniu Ordynariatu Polowego Wojska Polskiego. Organizacja duszpasterstwa wojskowego w III Rzeczypospolitej w dużej mierze była wzorowana na systemie organizacji służby duszpasterskiej w II Rzeczypospolitej. W niniejszym artykule przedstawiono historię posługi kapelanów wojskowych na ziemiach polskich do czasu utworzenia stałego duszpasterstwa wojskowego. Celem prezentowanej refleksji historycznej jest ukazanie początków służby duszpasterskiej i jej sukcesywnego rozwoju, dającego podstawy pod organizację opieki religijnej w Wojsku Polskim.

\section{Bibliografia (najważniejsze pozycje)}

Burzyński H., Struktura duszpasterstwa wojskowego w kościelnym prawie powszechnym, Radom 1999.

Chodyniecki D., Kapelani wojskowi w dziejach Polski do wybuchu II wojny światowej, „Saeculum Christianum” 4 (1997) nr 2, s. 105-153.

Góralski W., Struktura prawna duszpasterstwa wojskowego w świetle konstytucji apostolskiej papieża Jana Pawła II „Spirituali Militum Curae” z 21.IV.1986 r. „Prawo Kanoniczne" 32 (1989) nr 3-4, s. 143-155.

Humeński J., Zarys historyczny duszpasterstwa wojskowego w Polsce, w: Wspomnienia wojenne księży kapelanów, red. J. Humeński, Warszawa 1967, s. 9-42.

Klupa K., Katolickie duszpasterstwo wojskowe w Polsce do 1831 roku, „Poglądy i Doświadczenia" 1999 nr 113, s. 116-121.

Lenart M., Miles pius et iustus. Żolnierz chrześcijański katolickiej wiary w kulturze i piśmiennictwie dawnej Rzeczypospolitej (XVI-XVIII w.), Łódź 2009.

\footnotetext{
97 Według ks. Vincenta Josepha Rigdona konstytucja Spirituali Militum Curae stanowi początek „nowej ery” w dziedzinie organizacji i funkcjonowania ordynariatów polowych na świecie. Por. V. J. Rigdon, The Military Ordinariate of the United States of America in the New Code of Canon Law, Washington 1988, s. 1.
} 
Manthey J., Średniowieczne duszpasterstwo wojskowe, „Duszpasterz Polski Zagranicą" 9 (1958) nr 3, s. 259-277.

Nowak E., Rys dziejów duszpasterstwa wojskowego w Polsce 968-1831, Warszawa 1932.

Odziemkowski J., Historia Ordynariatu Polowego w Polsce, w: Przywrócenie Ordynariatu Polowego Wojska Polskiego, red. A. Kubicki, Warszawa 1991, s. 5-8.

Odziemkowski J., Stużba duszpasterska Wojska Polskiego 1914-1945, Warszawa 1998. Odziemkowski J., Frątczak S. Z., Polskie duszpasterstwo wojskowe, Warszawa 1996. Radziszewski J., $Z$ dziejów duszpasterstwa wojskowego w Polsce (do zakończenia I wojny światowej), „Wojsko i Wychowanie” 10 (1990), s. 40-43.

Sielicki F., Nieznane materiały do dziejów kapelaństwa polskiego, „Zeszyty Naukowe KUL" $1998 \mathrm{nr}$ 1-2, s. 186-194.

\section{Streszczenie}

Duchowa i żołnierska służba Bogu i ojczyźnie, stanowiąca szczególny wymiar powołania kapelanów wojskowych, ma długą historię sięgającą najdawniejszych czasów. Wraz z rozwojem organizacji armii, na przestrzeni wieków powstawały różne regulacje, próbujące unormować organizację posługi religijnej w wojsku i dostosować ją do potrzeb rozwijających się sił zbrojnych. To ważne zagadnienie stanowi przedmiot refleksji historycznej obejmującej swym zasięgiem służbę duszpasterską w Wojsku Polskim do czasu ukonstytuowania się stałego duszpasterstwa wojskowego.

\section{Słowa kluczowe}

Wojsko Polskie, duszpasterstwo wojskowe, kapelani wojskowi, armia, historia

\section{Summary}

\section{The History of the Army Ministration in Poland Until the Creation of the Permanent Ministration}

The spiritual and military service for God and homeland, being a particular aspect of callings for army chaplains, has a long history which reaches earliest times. Along with the development of army organisation different kinds of regulations have been formed which aimed at normalising the organisation of religious service in the 
army and adapting it to the needs of the developing services. This significant issue is the subject of historical reflexion covering the ministration in Polish Army until the permanent ministration was constituated.

\section{Keywords}

Polish Army, army ministration, army chaplains, army, history 